\title{
Community Forum: An Effective Program Planning Tool ${ }^{1}$
}

Lisa A. Guion ${ }^{2}$

\section{Overview}

One means by which educators can promote dialog about the needs in the county among diverse groups of constituents and stakeholders is to hold a community forum. A community forum is an excellent program-planning tool because it can promote thoughtful discussions where many different points of view are shared. It also affords community members the opportunity to share specific information about emerging program opportunities and needs, as well as provide broadbased input from key clientele groups concerning their priorities for future educational programs. Also, a community forum has many other benefits because it:

- $\quad$ is an interactive way of providing opportunities for immediate feedback and clarification of issues;

- can be broad enough to address issues of concern across program areas, or specific enough to focus on one area;

- can provide a focus for interagency cooperation in addressing critical issues more so than many other techniques;

- can be a media event attracting additional involvement and support;

- legitimizes future program plans; clientele are more likely to support and participate in county programs for which they have had prior input; and

- provides opportunities to attract and involve new clientele or attract new volunteers (Cornell 2003).
There are primarily two common ways in which community forums are conducted. One method is to have a facilitator who will ask openended, broad questions such as "What are some of the key problems/issues facing youth (or whatever your subject area is) that you would like to see addressed in this community and why?" Then, have an open microphone whereby audience members can express their feelings (most pressing concerns on their minds). The facilitator, in this case, must be very skilled at controlling the flow of meetings, soliciting audience participation and monitoring time. This method is excellent when the educator wants to know exactly what is in the hearts and minds of the constituents/target audience. It is also helpful if there are no existing statistics or information/secondary data on the problems/needs/ issues; or, if that information is old or unreliable.

Another, more widely used method, involves inviting panelists, who represent different crosssections of the community, to discuss their viewpoints on selected issues, then encouraging the audience to respond and contribute to the discussion. Using the example above, the panelist will speak on a specific issue(s) such as youth delinquency, education, recreation, health, etc. This method allows the educator to determine the topics for the discussion in advance. This method is used when the educator has good evidence (data and existing statistics) about the key problems, but wants to learn more specific

1. This document is PE070, one of a series of the Department of Family, Youth and Community Sciences, Florida Cooperative Extension Service, IFAS, University of Florida, Gainesville, FL 32611: First published: October 2003. Reviewed by Elizabeth Bolton, Ph.D., Department of Family, Youth and Community Sciences; and Lamont Flowers, Ph.D., assistant professor, Department of Educational Leadership, Policy and Foundations, University of Florida, Gainesville, FL 32608. Please visit the EDIS Web site at http://edis.ifas.ufl.edu

2. Lisa A. Guion, Ed.D., assistant professor, Department of Family, Youth and Community Sciences, University of Florida, Gainesville, FL 32611.

The Institute of Food and Agricultural Sciences is an equal opportunity/affirmative action employer authorized to provide research, educational information and other services only to individuals and institutions that function without regard to race, color, sex, age, handicap or national origin. For information on obtaining other extension publications, contact your county Cooperative Extension Service office. Florida Cooperative Extension Service/Institute of Food and Agricultural Sciences/University of Florida/Christine Taylor Waddill, Dean. 
information from the stakeholders/target audience. Given that it is easy for audience members to stray away from topics at hand, using a facilitator with this method is also recommended. This method would be helpful in exploring more detailed information about predetermined needs in the community.

To summarize, regardless of the methods used, community forums can promote reflective and inclusive discourse on significant problems and issues in the community (ASCD 2003). A community forum allows input into Extension programming beyond the limited members of the county/program advisory committee. It also can facilitate a more in-depth understanding of the needs/problems/issues in a community. The second article (PD060) in this two-part series will discuss key strategies for conducting community forums as well as ways to avoid common pitfalls.

\section{References}

Conducting a community forum. Retrieved from Cornell Cooperative Extension website on August 22, 2003 at http://www.cce.cornell.edu/admin/program/document s/townmtg.htm

Lukas, C. and Hoskins, L. 2003. Conducting community forums: Engaging citizens, mobilizing communities. St. Paul, MN: Wilder Publications.

Setting up community events and forums. Retrieved from the Association for Supervision and Curriculum Development (ASCD) website on August 21, 2003 at http://www.ascd.org/advocacykit/setting_up.html 